\title{
INTERNALISASI APLIKASI MIND MAP PADA MEDIA PEMBELAJARAN GURU UNTUK MENINGKATKAN KOMPETENSI SISWA DALAM MEMPRODUKSI TEKS PROSEDUR
}

\author{
Patmawati \\ Program Studi Bahasa Indonesia, Fakultas Ilmu Budaya Universitas Hasanuddin \\ amma.patma@yahoo.com \\ Nurhayati \\ Program Studi Bahasa Indonesia, Fakultas Ilmu Budaya Universitas Hasanuddin \\ nurhayatisyair@gmail.com \\ Ade Yolanda Latjuba \\ Program Studi Sastra Prancis, Fakultas Ilmu Budaya Universitas Hasanuddin \\ aylatjuba@gmail.com
}

\begin{abstract}
This study aims (1) to explain the learning outcomes of Mind Map applications to improve the ability of Grade XI students of the Department of Network Computer Engineering at SMK Negeri 3 Makassar in producing procedure texts and (2) to explain and analyze the effectiveness of Mind map applications to improve the ability of SMK Negeri 3 Makassar students in producing procedure texts. This type of research is a class action or abbreviated with CAR. In this study there were no comparison classes. The experimental class as well as the control class. In its implementation several cycles are applied. The results showed: (1) An increase in student learning outcomes during the learning process took place with the learning of Mind map applications. Learning outcomes in the first cycle obtained an average value of 74.75 and the second cycle reached an average value of 84.06. Improved mastery learning outcomes classically is $31.25 \%$ with an average value of 9.31 and the final test score classically is 90.03. (2) With the Mind Mind application learning and teaching psychology approach to students, this proves that the mastery of learning to improve student competence in producing procedural texts has reached the specified KKM that is $75 \%$ and has been effective and the results are very good compared to learning with methods conventional.
\end{abstract}

Keyword: Class room research, Mind Map, Procedure Text

\section{PENDAHULUAN}

Pendidikan adalah hal yang paling penting dalam kehidupan manusia. Melalui pendidikan, Indonesia dapat meningkatkan kualitas SDM sehingga mampu bersaing dengan negara lain. Setiap tingkat pendidikan mulai dari SD, SMP, SMA dan SMK belajar mata pelajaran Bahasa Indonesia. Penelitian ini berfokus pada proses pembelajaran di sekolah menengah kejuruan.

Pembelajaran Bahasa Indonesia di Sekolah Menengah Kejuruan (SMK) sedikit berbeda dengan Sekolah Menengah Atas (SMA). Pembelajaran bahasa Indonesia di
SMA memiliki materi dibandingkan di di SMK. Di SMK siswa lebih diprioritaskan pada keterampilannya dibanding akademiknya. Sementara di SMA lebih diprioritaskan akademik karena alumni atau lulusan SMA lebih banyak yang lanjut ke Perguruan Tinggi. Namun kedua jenis sekolah tersebut pada akhirnya tujuan yang sama yaitu mencapai tujuan pembelajaran. Keterampilan menulis sangat penting bagi pembelajaran siswa karena mereka perlu memiliki keterampilan berpikir yang kreatif dan aktif, serta harus berkreasi semaksimal mungkin untuk menyuntikkan pikirannya ke dalam bahasa tulis. Salah satu komunikasi tertulis yang dapat digunakan 


\section{3 | JURN AL ILMU BUDAY}

Volume 8, Nomor 2, Tahun 2020

untuk menyampaikan makna kepada pembaca atau orang lain adalah dengan menulis teks prosedur, dan salah satu teks yang diajarkan di jenjang SMK adalah teks prosedur.

Tujuan teks prosedur adalah memberikan informasi tentang langkahlangkah atau tahapan yang harus dilakukan untuk mencapai tujuan agar pembaca dapat mengeksekusi apa yang tertulis dalam teks tersebut. Kita dapat menemukan penggunaan teks prosedur dalam kehidupan sehari-hari. Pembelajaran menulis teks program juga sangat diperlukan untuk mendidik siswa sekolah agar memiliki keterampilan dan aturan menulis yang kuat dan benar dalam kehidupan sosial.

Keterampilan menulis teks akan menjadi bahan analisis dalam penelitian ini khususnya kemampuan siswa memproduksi teks prosedur melalui aplikasi mind map. Agustina (2017) menyatakan bahwa hakikat pembelajaran bahasa Indonesia berbasis teks dalam kurikulum 2013 di SMK dan di SMA adalah kemampuan berpikir siswa dapat dikembangkan dan materi pembelajaran berupa teks menetapkan capaian kompetensi siswa yang mencakup tiga ranah pendidikan: sikap, pengetahuan, dan keterampilan.

Telah dilakukan survei awal terhadap kompetensi siswa melalui guru mata pelajaran bahasa Indonesia kelas XI TKJ 1 di SMK Negeri 3 Makassar pada tanggal 26 Juli 2019. Survey yang dilakukan adalah permasalahan dalam memproduksi teks prosedur, dan hasil survey tersebut ditemukan kesenjangan antara harapan dan kenyataan. Hasil survei menunjukkan bahwa nilai rata-rata yang belum mencapai Kriteria Ketuntasan Minimal (KKM) yaitu 75 atau masih kategori cukup karena ketuntasan belajarnya tidak memenuhi indikator penilaian KKM secara klasikal 75\%.

Salah satu faktor penting untuk menentukan capaian pembelajaran adalah penggunaan metude pembelajaran. Metode pembelajaran yang digunakan guru dalam strategi pengajaran juga menunjang keefektifan proses belajar siswa. Penentuan Metode pembelajaran yang tepat dapat meningkatkan kemampuan siswa dalam memahami materi yang diajarkan oleh guru.

Ada beberapa model pembelajaran yang biasanya digunakan oleh guru dalam membawakan materi ajar teks prosedur ini, diantaranya model active learning. Akan tetapi, kondisi kelas yang berbeda memerlukan model pembelajaran yang sesuai dengan keadaan siswa di dalam kelas. Pada survei yang dilakukan sebelumnya di sekolah, diperoleh informasi dari guru mata pelajaran yang mengajar di kelas yang akan menjadi sampel penelitian bahwa sebagian besar siswa di kelas tersebut sulit memahami pelajaran yang diberikan.

Hal ini dapat dibuktikan dengan nilai Ulangan Semester ganjil siswa kelas XI TKJ 1 SMK Negeri 3 Makassar tahun pelajaran 2019/2020 sebelum diadakan perbaikan, siswa yang mencapai kriteria ketuntasan minimal (KKM) adalah 12 orang siswa atau $37,5 \%$ dari 28 jumlah keseluruhan siswa. Siswa yang belum mencapai kriteria ketuntasan minimal (KKM) sebanyak 20 siswa atau 62,5\%. Kondisi siswa pada kelas demikian membutuhkan peran guru yang lebih dominan dan metode yang tepat.

Menurut Mulyasa (2006), guru harus menentukan Metode pembelajaran dan mengembangkannya untuk meningkatkan aktivitas dan kreativitas peserta didik. Di sekolah, guru dapat memilih metode, teknik, media yang sesuai dengan kebutuhan. Akan tetapi, kadang kala guru kurang berinovasi dab hanya berpatokan pada metode yang ada pada buku cetak saja sehingga pembelajaran tidak kondusif.

Salah satu upaya peningkatan hasil belajar siswa adalah penerapan metode mind map. Tujuan penggunaan metode ini adalah meningkatkan kemampuan siswa kelas XI TKJ 1 untuk memproduksi teks prosedur pada mata pelajaran Bahasa 
Indonesia. Mind map adalah metode pembelajaran yang dirancang untuk membantu siswa menentukan dan mengkompilasi pengetahuan inti, yang dapat meningkatkan pemahaman siswa tentang materi pembelajran.

Mind map sangat penting digunakan dalam pengajaran yaitu ketika ujian (Edwards, 2010). Selain itu, mind map digambarkan sebagai teknik studi yang efektif ketika diterapkan pada bahan tertulis. Mind map adalah potert kemampuan dan proses berpikir alami otak yang dipresentasikan melalui gambar (Buzan, 2012).

Salah satu keunggulan metode ini, yaitu meningkatkan kreativitas dan memotivasi siswa dalam menuangkan gagasannya. Metode mind map adalah metode inovatif dan efektif dalam mengingat sesuatu dengan lebih baik daripada cara membaca teks yang rutin serta menjadikan siswa kreatif karena mengaktifkan kedua bagian otak kanan dan kiri dengan adanya visualisasi gambar, warna dan simbol.

Berdasarkan latar belakang yang telah diuraikan, masalah dapat dirumuskan sebagai berikut, "Bagaimana hasil peningkatan kemampuan pembelajaran memproduksi teks prosedur melalui aplikasi mind map?"

Tujuan dari penelitian ini adalah untuk menjelaskan dan menganalisis efektivitas pembelajaran memproduksi teks prosedur melalui aplikasi mind map dalam meningkatkan kemampuan siswa kelas XI TKJ 1 di SMKN 3 Makassar.

\section{KAJIAN TEORETIS}

Bahasa merupakan sarana untuk mengungkapkan gagasan, dan gagasan yang lengkap biasanya diwujudkan dalam bentuk teks. Teks diartikan sebagai ucapan atau tulisan, yang artinya memiliki awal dan akhir. Pembelajaran bahasa Indonesia berbasis teks merupakan proses pembelajaran yang dilakukan oleh masyarakat Indonesia yang diawali dengan memahami teks dan bermuara pada penciptaan teks (Baryadi, 2016).

Teks merupakan satuan bahasa terbesar atau terlengkap, termasuk teks lisan dan teks tertulis (Saputra et al., 2020). Berdasarkan asumsi tersebut, maka fungsi komunikasi bahasa adalah untuk mengembangkan kemampuan memahami dan membuat teks, karena komunikasi terjadi pada tataran teks atau teks. Pembelajaran berbasis teks ini digunakan sebagai dasar untuk pengembangan keterampilan dasar dalam pengetahuan dan keterampilan dalam kurikulum bahasa Indonesia tahun 2013.

Kata teks berasal dari bahasa latin yang artinya menenun (Mulyana, 2017). Pembelajaran berbasis teks adalah pembelajaran yang ditujukan untuk kemampuan siswa menulis teks. Pembelajaran berbasis teks melibatkan proses di mana guru akan membantu siswa membuat teks dan secara bertahap mengurangi bantuan ini sampai siswa dapat membuat teks sendiri.

Pembelajaran berbasis teks bukanlah hal baru. Pembelajaran berbasis teks telah dilakukan dalam mata pelajaran menulis dan membaca di Sekolah Menengah Gratis di Amerika Serikat. (Riski et al., 2018). Dalam situasi berbasis teks, siswa tidak hanya menggunakan bahasa sebagai alat komunikasi, tetapi juga menggunakannya sebagai alat untuk mengembangkan keterampilan berpikir. Tujuan teori pembelajaran berbasis teks adalah melaksanakan berbagai kegiatan komunikasi yang bermakna terkait dengan teks, dan bermanfaat bagi kehidupan siswa dalam hal penerimaan dan produktivitas. Artinya teks penelitian bukan sebagai tujuan akhir, melainkan sebagai alat untuk melaksanakan berbagai kegiatan yang berkaitan dengan kehidupan nyata. Emilia (terbitan Mulyana 2017) menyebutkan prinsip-prinsip utama pembelajaran berbasis teks sebagai berikut. 
a. Menekankan

pentingnya pengembangan kesadaran siswa oleh guru, yaitu, setiap teks adalah ciptaan unik dari seorang penulis yang unik, dan berhubungan dengan sekelompok orang dan lingkungan tertentu.

b. Pikirkan pembelajaran bahasa sebagai aktivitas sosial. Melalui prinsip tersebut, pembelajaran bahasa berbasis teks diharapkan menghasilkan tiga hal, yaitu: siswa belajar bahasa, belajar melalui bahasa dan belajar bahasa.

c. Jika guru secara eksplisit mengajar merangsang siswa untuk berpartisipasi dalam proses pembelajaran, dan memiliki kemandirian dalam menulis, serta dapat mendiskusikan bagaimana menggunakan bahasa dalam berbagai konteks nyata, seperti persuasi atau persuasi, pembelajaran akan lebih efektif.

d. Dalam rangka magang, belajar di bawah bimbingan guru. Dalam proses pengajaran, guru harus berperan sebagai ahli untuk membantu siswa berhasil belajar bahasa, sedangkan siswa adalah orang yang terlatih.

e. Dengan bantuan pengajaran tata bahasa berdasarkan fungsi tata bahasa dari teks yang bersangkutan, diharapkan siswa dan guru dapat menulis, membaca, mendengarkan dan berbicara, serta mengevaluasi apakah teks/tulisan yang ditulis oleh seseorang merupakan jenis teks yang wajib diisi dan diajarkan.

Berdasarkan beberapa pendapat ahli di atas, dapat disimpulkan bahwa pembelajaran berbasis teks merupakan teori pembelajaran, berorientasi pada semua aktivitas dalam lingkup bahasa, dan semua aktivitas yang bermakna bagi bahasa lisan dan tulisan. Menurut Sarimanah (2017), dalam melaksanakan kegiatan pembelajaran berbasis teks, langkahlangkah pengembangan teks dalam pembelajaran bahasa Indonesia dapat dilakukan dalam empat tahap. Tahapan tersebut meliputi: membangun konteks teks, pemodelan teks, teks bangunan kelompok, dan membangun teks mandiri. Tahap konstruksi konteks dimaksudkan sebagai langkah awal bagi guru dan siswa untuk membimbing pemikirannya pada topik yang akan dibahas di setiap kelas. Tahap pemodelan teks berisi pembahasan tentang teks yang disediakan sebagai model pembelajaran. Diskusi membahas semua aspek bahasa yang membentuk keseluruhan teks.

Tahap pembuatan teks secara berkelompok. Pada tahap ini siswa menyusun teks sesuai model sesuai struktur teks dari jenis teks yang diminta. Pada tahap membuat teks secara mandiri, pada tahap ini siswa membuat teks secara terpisah berdasarkan pengalamannya dalam menulis teks secara berkelompok. Dengan cara ini diharapkan siswa dapat menggunakan teks untuk merealisasikan dirinya sesuai dengan jenis dan karakteristik yang ditunjukkan pada model teks.

Penelitian ini berfokus pada teks prosedur. Teks program adalah teks yang berisi program yang melanjutkan langkah demi langkah atau membangun struktur urutan untuk menghasilkan tujuan yang diinginkan. Dalam proses teks terdapat kata imperatif yang dapat melengkapi konten yang dibahas dalam teks tersebut, sehingga pembaca dapat melakukan operasi yang memberitahukan konten teks tersebut.

Teks prosedur sangat penting bagi siswa, karena siswa sering menjumpainya dalam kehidupan sehari-hari di masyarakat. Tujuannya adalah untuk memberikan penjelasan yang jelas tentang langkahlangkah dalam melakukan sesuatu. Menurut Kosasih (2014), teks prosedur adalah "teks lengkap, jelas dan rinci menjelaskan langkah-langkah yang terlibat." Teks prosedur tidak hanya melibatkan penggunaan alat, tetapi dapat juga mencakup cara melakukan aktivitas dan kebiasaan gaya hidup tertentu.

Sarimanah (2017) membagi tahapan pembelajaran bahasa berbasis teks menjadi empat tahapan, yaitu: (1) Menetapkan 
konteks teks. Tahap penetapan konteks ini dimaksudkan sebagai langkah awal bagi guru dan siswa untuk mengarahkan pemikiran mereka pada topik yang akan dibahas di setiap mata kuliah; (2) Pemodelan teks. Tahap pemodelan merupakan penggalan teks yang berisi pembahasan tentang teks yang diberikan sebagai model pembelajaran. Diskusi membahas semua aspek bahasa yang membentuk keseluruhan teks. (3) Membuat teks dalam kelompok. Pada tahap ini, siswa menyusun teks secara berkelompok sesuai dengan struktur teks dari jenis teks yang dibutuhkan seperti yang ditunjukkan pada model. (4). Membuat teks secara mandiri. Pada tahap ini siswa akan membuat teks secara terpisah berdasarkan pengalamannya sendiri dalam membuat teks kelompok.

Selanjutnya, langkah-langkah metode Mind Map akan dibahas. Menurut Buzan (2010) ada tujuh langkah dalam pembuatan peta pikiran yaitu:

1) Mulailah dari tengah kertas putih dan letakkan sisi panjangnya rata, karena mulai dari tengah dapat membuat otak leluasa berkembang ke segala arah;

2) Gunakan gambar atau simbol sebagai ide sentral, karena gambar berarti ribuan kata dan dapat membantu kita menggunakan imajinasi kita;

3) Gunakan warna, karena warna menarik bagi otak seperti gambar. Wrna membuat peta pikiran lebih hidup dan hidup, menambah vitalitas pada pemikiran kreatif dan menarik;

4) Hubungkan cabang utama ke gambar pusat (ide utama), dan hubungkan cabang ke tingkat kedua dan ketiga, dan kemudian ke tingkat pertama dan kedua. Dengan cara ini, karena otak bekerja sesuai dengan asosiasi, otak suka menghubungkan dua atau tiga dan empat hal sekaligus'

5) Gambarlah sebuah kurva, bukan garis lurus, karena garis lurus akan mengganggu otak;

6) Gunakan hanya satu kata kunci per baris, karena satu kata kunci memberikan fungsi dan fleksibilitas yang hebat untuk peta pikiran;

7) Gunakan gambar, karena setiap gambar berarti seribu kata seperti gambar pusat.

Salah satu faktor penentu

keberhasilan siswa di sekolah adalah faktor psikologis (kecerdasan, perhatian, minat, motivasi, kematangan, sikap dan persiapan). Psikologi merupakan elemen dasar dalam proses belajar mengajar antara guru dan siswa (Cahya, 2017). Psikologi pendidikan membantu menggali potensi belajar siswa, karena setiap orang memiliki kemampuan dan tingkat kecerdasan yang berbeda.

Psikologi pendidikan membantu guru membedakan potensi belajar siswa dari perspektif kecerdasan, perkembangan intelektual, emosi dan perkembangan, serta motivasi atau dorongan. Tanpa pemahaman penuh tentang psikologi pendidikan, guru akan kesulitan untuk menunjukkan bahwa mereka adalah fasilitator dan promotor pembelajaran siswa. Peran psikologi pendidikan, dapat mengajarkan kepada pendidik bagaimana memahami kondisi psikologis dan menciptakan suasana belajar yang bermanfaat, sehingga proses pembelajaran di kelas dapat terlaksana dengan efektif. Lingkungan sekolah merupakan wadah untuk menumbuhkan keterampilan berpikir dan dapat menjadi penerus penguasaan ilmu pengetahuan dan teknologi.

\section{METODE PENELITIAN}

Jenis penelitian mencakup metode penelitian kuantitatif, kualitatif, penelitian dan pengembangan (Research \& Development), dan penelitian tindakan. Metode penelitian kuantitatif dipilih jika peneliti akan mendukung, melakukan pengembangan atau menolak sebuah teori. Metode penelitian kuantitatif bercirikan dengan hipotesa.

Jenis penelitian yang dilakukan adalah penelitian tindakan kelas (classroom 


\section{7 | JURNAL ILMU BUDAYA}

Volume 8, Nomor 2, Tahun 2020 action research) yang dikenal dengan PTK. Penelititan tindakan kelas merupakan tindakan atau usaha di dalam proses pembelajaran guna meningkatkan hasil belajar siswa (Junaidi et al., 2020. Penelitian tindakan kelas dilakukan secara kolaboratif antara guru dan peneliti.

Penelitian tindakan kelas ini telah dilaksanakan di SMK Negeri 3 Makassar. Sampel dalam penelitian ini adalah kelas XI TKJ 1 dengan jumlah 32 siswa. Penelitian ini mengikuti rancangan penelitian tindakan kelas yang dikembangkan oleh Kemmis dan Mc Taggart (dalam Arikunto, 2010). Langkah-langkah penelitian tindakan kelas iterdiri atas dua siklus. Setiap siklus terdiri atas empat komponen pokok, yaitu perencanaan, pelaksanaan tindakan, pengamatan, dan refleksi. Keempat langkah tersebut merupakan satu siklus. Setelah langkah ke empat dilakukan, pendidik kembali lagi ke langkah pertama, begitu seterusnya.

Pengolahan data dilakukan dengan pendekatan PTK. Desain penelitian eksperimen one group pre-test post-tes design yaitu eksperimen yang dilaksanakan pada satu kelompok saja tanpa kelompok pembanding. Metode ini digunakan untuk mengetahui efektivitas dan seberapa besar peningkatan hasil belajar setelah menerapkan mind map.

Peningkatan kemampuan siswa ditunjukkan dengan peningkatan nilai yang diperoleh pada setiap siklus dan tes akhir. Parameter untuk mengetahui tingkat keberhasilan siswa memproduksi teks prosedur melalui aplikasi mind map dapat dilihat pada tabel 1 .

Tabel 1. Konversi nilai

\begin{tabular}{|c|c|c|c|c|c|c|}
\hline \multirow{2}{*}{\multicolumn{2}{|c|}{ INTERVAL }} & NILAI & PRED & NILAI & PRED & \multirow[t]{2}{*}{ SIKAP } \\
\hline & & \multicolumn{2}{|c|}{ PENGETAHUAN } & \multicolumn{2}{|c|}{ KETRAMPILAN } & \\
\hline $96 \mathrm{~s} / \mathrm{d}$ & 100 & 4.00 & A & 4.00 & A & \multirow{2}{*}{$\begin{array}{c}\text { Sangat baik } \\
\text { (A) }\end{array}$} \\
\hline $91 \mathrm{~s} / \mathrm{d}$ & 95 & 3.66 & A- & 3.66 & A- & \\
\hline $86 \mathrm{~s} / \mathrm{d}$ & 90 & 3.33 & $\mathrm{~B}+$ & 3.33 & $\mathrm{~B}+$ & \multirow{3}{*}{ Baik (B) } \\
\hline $81 \mathrm{~s} / \mathrm{d}$ & 85 & 3.00 & $B$ & 3.00 & $B$ & \\
\hline $76 \mathrm{~s} / \mathrm{d}$ & 80 & 2.66 & B- & 2.66 & B- & \\
\hline $71 \mathrm{~s} / \mathrm{d}$ & 75 & 2.33 & $\mathrm{C}+$ & 2.33 & $\mathrm{C}+$ & \multirow{3}{*}{ Cukup (C) } \\
\hline $66 \mathrm{~s} / \mathrm{d}$ & 70 & 2.00 & C & 2.00 & C & \\
\hline $61 \mathrm{~s} / \mathrm{d}$ & 65 & 1.66 & C- & 1.66 & C- & \\
\hline $56 \mathrm{~s} / \mathrm{d}$ & 60 & 1.33 & $\mathrm{D}+$ & 1.33 & D+ & \multirow{2}{*}{ Kurang (D) } \\
\hline$\ldots . \quad s / d$ & 55 & 1.00 & D & 1.00 & D & \\
\hline
\end{tabular}

(Modifikasi dari Maolani, 2020)

Tabel konversi nilai di atas sebagai pedoman penilaian aktivitas selama kegiatan pembelajaran pada siklus I dan siklus II. Dengan kriteria jika dapat nilai 4 kategori sangat baik. Nilai 3 kategori Baik, nilai 2 kategori cukup.

Nilai Hasil Belajar Siswa

Analisis nilai hasil belajar siswa dilakukan untuk mengetahui apakah terjadi peningkatan hasil belajar melalui penerapan metode mind map, dianalis menggunakan klasifikasi penelitian yaitu dengan menentukan skor pada setiap indikator sesuai dengan pedoman penskoran yang telah ditetapkan yaitu menghitung presentase rata-rata tiap indikator untuk mengetahui ketuntasan klasikal (bersamasama di dalam kelas) dan daya serap 
klasikal dari setiap indikator dengan menggunakan rumus berikut:

$$
\mathrm{KS}=\frac{N T}{N} \times 100 \%
$$

Keterangan:

$\mathrm{KS}=$ Ketuntasan Klasikal

NT = Jumlah Siswa yang Tuntas

N= Jumlah Siswa Keseluruhan

(Sumber: Sukardi, 2004)

\section{HASIL DAN PEMBAHASAN}

\section{Peningkatan Hasil Pembelajaran Memproduksi Teks Prosedur Melalui Aplikasi Mind Map Untuk} Meningkatkan Kemampuan Siswa
Data yang diperoleh pada siswa kelas XI TKJ 1 yaitu data hasil kemampuan siswa dalam memproduksi teks prosedur pada mata pelajaran bahasa Indonesia siklus I, siklus II, dan tes akhir (post-test) yang diperoleh setelah perlakuan berupa pembelajaran dengan aplikasi mind map telah memperlihatkan hasil yang baik. Hal ini dapat dibuktikan oleh pencapaian peningkatan nilai dari siklus I yaitu 74,75 atau $62,5 \%$ mengalami peningkatan siklus II yaitu 84,O6 atau 93,75\%. Pada hasil nilai tes akhir (post-test) sebesar 90,O3 melebihi nilai KKM yang telah ditetapkan. Hasil peningkatan belajar siswa dari siklus I ke siklus II yaitu $31,25 \%$. Hal ini dapat dilihat pada tabel 2 .

Tabel 2. Hasil peningkatan belajar siswa

\begin{tabular}{|c|c|c|c|c|c|c|}
\hline No & Siklus & $\begin{array}{c}\text { Jumlah } \\
\text { siswa } \\
\text { Tuntas }\end{array}$ & $\begin{array}{c}\text { Jumlah } \\
\text { siswa } \\
\text { Tidak } \\
\text { Tuntas }\end{array}$ & $\begin{array}{c}\text { Skor } \\
\text { yang } \\
\text { dicapai }\end{array}$ & $\begin{array}{l}\text { Rata- } \\
\text { rata }\end{array}$ & $\begin{array}{c}\text { Ketuntasan } \\
\text { Klasikal }\end{array}$ \\
\hline 1 & Siklus I & 20 & 12 & 2392 & 74,75 & $62,5 \%$ \\
\hline 2 & Siklus II & 30 & 2 & 2690 & 84,06 & $93,75 \%$ \\
\hline \multicolumn{5}{|c|}{ Jumlah Peningkatan } & 9,31 & $31,25 \%$ \\
\hline
\end{tabular}

Tabel di atas menunjukkan bahwa hasil belajar secara klasikal (bersama-sama di kelas) telah tercapai pada siklus II. Dari tabel tersebut menunjukkan bahwa adanya peningkatan ketuntasan hasil belajar siswa melalui aplikasi mind map yaitu sebesar $31,25 \%$. Nilai rata-rata pada siklus I yaitu 74,75 dan mengalami peningkatan pada siklus II yaitu 84,06.

Agar lebih sempurna dan hasilnya lebih jelas peneliti membuat gambar diagram batang hasil peningkatan belajar siswa dalam memproduksi Teks prosedur dari siklus I dan mengalami peningkatan pada siklus II, setelah diterapkan pembelajaran aplikasi mind map pada media guru untuk meningkatkan kemampuan siswa dalam memproduksi teks prosedur dapat dilihat pada gambar 1 . . 


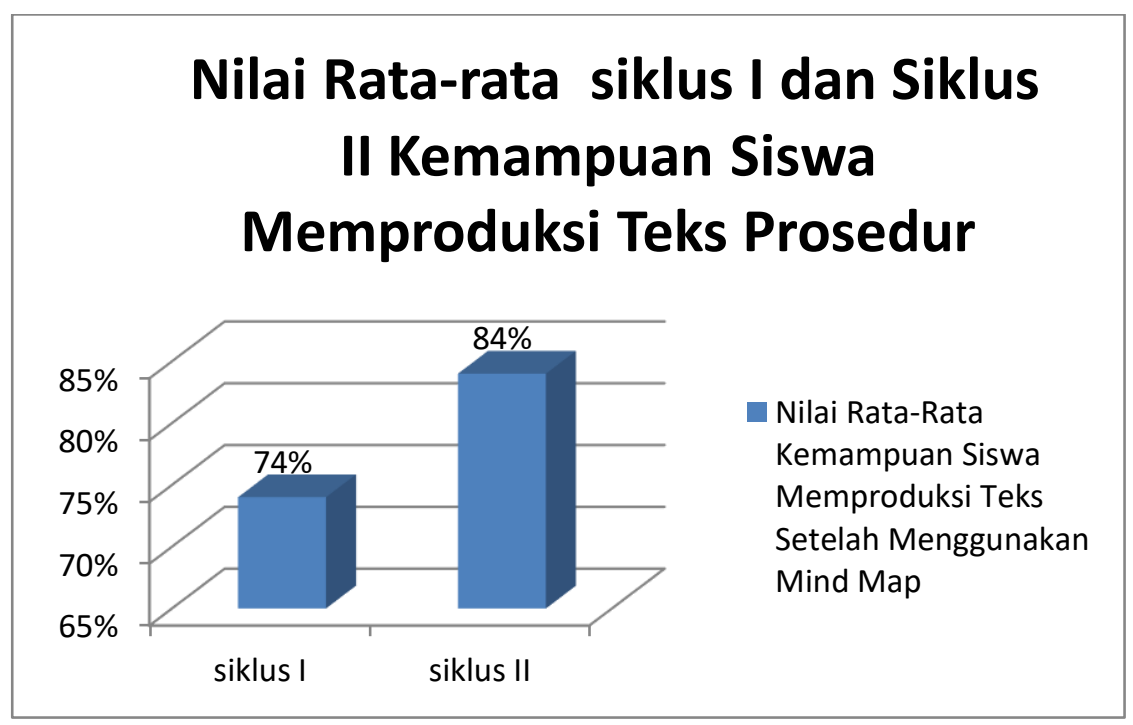

Gambar 1.

Bagan di atas dapat disimpulkan hasil belajar kemampuan siswa dalam memproduksi teks prosedur pada indikator penilaian (isi, struktur dan bahasa) melalui pembelajaran aplikasi mind map pada siklus I yaitu nilai rata-rata siswa secara klasikal 74,75 atau $62,5 \%$ siswa yang tuntas atau mencapai keberhasilan belajar. Pada siklus II mengalami peningkatan nilai rata-rata siswa secara klasikal (bersama-sama di dalam kelas) 84,06 atau 93,75\% siswa mencapai ketuntasan belajar.

Efektivitas Penerapan Pembelajaran Memproduksi Teks Prosedur Melalui Aplikasi Mind Map Untuk Meningkatkan Kemampuan Siswa

Efektivitas pembelajaran teks prosedur melalui aplikasi mind map dapat dilihat dari hasil belajar siswa. Hasil belajar siswa yaitu terdiri atas hasil nilai pre-tes, siklus I, siklus II, dan nilai hasil post-tes. Nilai pre-tes diperoleh dari hasil tes sebelum pembelajaran aplikasi mind map, sedangkan nilai siklus I, II dan posttes diperoleh dari hasil tes sesudah pembelajaran aplikasi mind map. Nilai hasil pre-tes, siklus I, siklus II dan post-tes mengalami perbedaan.

Berdasarkan data pembelajaran pada saat pre-tes diperoleh nilai paling tinggi 90 dan nilai paling rendah 20 dengan nilai rata-rata secara klasikal yaitu 50,31. Hal ini menunjukkan adanya perbedaan yang signifikan setelah pembelajaran aplikasi mind map diterapkan diperoleh nilai rata-rata secara klasikal pada siklus I yaitu 74,75, pada siklus II diperoleh nilai rata-rata secara klasikal yaitu 84,06 dan nilai rata-rata post-tes atau tes akhir yaitu 90,03. Agar lebih jelas dapat dilihat pada tabel berikut ini. 


\section{0 | JURN AL ILMU BUDAY}

Volume 8, Nomor 2, Tahun 2020

Tabel 3. Keefektifan Hasil Peningkatan Belajar Siswa

\begin{tabular}{|c|c|c|c|}
\hline NO & Hasil Pembelajaran & Nilai Rata-rata & $\begin{array}{c}\text { Ketuntasan } \\
\text { Klasikal }\end{array}$ \\
\hline 1 & Pre-tes & 50,31 & $18,75 \%$ \\
\hline 2 & Siklus I & 74,75 & $62,5 \%$ \\
\hline 3 & Siklus II & 84,06 & $93,75 \%$ \\
\hline 4 & Post-tes (Nilai tes akhir) & 90,03 & $100 \%$ atau \\
& & & $\begin{array}{c}\text { mencapai nilai } \\
\text { KKM } \geq 75\end{array}$ \\
\hline
\end{tabular}

Data di atas menunjukkan perbedaan. Pada saat pre-tes siswa yang tuntas sebanyak 6 orang atau 18,75\% dari 32 siswa. Kemudian pada siklus I siswa yang tuntas 20 orang atau $62,5 \%$ dengan nilai rata-rata 74,75 dan mengalami peningkatan pada siklus II hasil kemampuan siswa dalam memproduksi teks prosedur yaitu 30 orang atau 93,75\% siswa yang tuntas dengan nilai rata-rata diperoleh secara klasikal yaitu 84,06. Diakhir pertemuan penelitian agar hasil maksimal dan untuk mencapai ketuntasan belajar yang telah ditetapkan yaitu $75 \%$, siswa dapat mencapai ketuntasan tersebut dengan nilai rata-rata diperoleh yaitu 90,03. Dengan demikian dapat disimpulkan Pembelajaran aplikasi mind map di SMK 3 Makassar Kelas XI Jurusan Teknik Komputer Jaringan sudah efektif dilaksanakan.

Efektivitas penerapan pembelajaran memproduksi teks prosedur melalui aplikasi mind map juga dapat dilihat dengan adanya pendekatan psikologi pendidikan khususnya pada siswa yang tidak aktif dalam proses pembelajaran sehingga menjadi aktif. Psikologi pendidikan sangat berkontribusi positif pada pembelajaran aplikasi mind map terhadap peningkatan kemampuan siswa dalam memproduksi teks prosedur sehingga hasil nilai post-tes meningkat.

\section{KESIMPULAN}

Berdasarkan proses, hasil, dan pembahasan dalam penelitian ini, dapat disimpulkan beberapa hal berikut ini: Keberhasilan belajar siswa ditentukan oleh pedagogik seorang guru karena guru adalah desainer generasi masa depan anak. Melalui sentuhan Aplikasi mind map media pembelajaran guru merupakan salah satu alternatif untuk meningkatkan kompetensi siswa dalam memproduksi teks prosedur sangat penting dan bermanfaat karena melalui salah satu pembelajaran aplikasi mind map dapat merubah cara belajar siswa menjadi lebih menarik dan menyenangkan dengan visualisasi warna-warni, symbol dan gambar dan menguatkan daya ingat karena adanya kerjasama otak kanan dan otak kiri. Peningkatan pembelajaran teks prosedur melalui aplikasi mind map dari siklus I ke siklus II yaitu sebesar 31, 25\%. Kemampuan siswa SMK Negeri 3 Makassar dalam memproduksi teks prosedur setelah menerapkan aplikasi mind map mengalami peningkatan. Hal tersebut dapat dilihat dari hasil belajar siswa pada kelas XI TKJ 1. Hasil belajar siswa pada kelas tersebut memperlihatkan perbedaan yang cukup signifikan. Siklus I mencapai nilai rata-rata 74,75 yang berarti belum maksimal dan siklus II mencapai nilai ratarata 84,06 yang berarti berada pada katgori baik. Hal ini menunjukkan bahwa hasil belajar siswa dalam memproduksi teks prosedur sudah efektif. 
Berdasarkan simpulan hasil penelitian di atas, saran yang dapat disampaikan penulis adalah (1) Kepada guru bahasa Indonesia, perlu diterapkan model-model pembelajaran yang lebih inovatif agar proses pembelajaran lebih menarik. Karena Guru adalah desainer generasi masa depan bangsa; (2) Melalui aplikasi mind map dalam pembelajaran berbasis teks khususnya teks prosedur pada mata pelajaran bahasa Indonesia dapat meningkatkan kompetensi siswa baik pada ranah afektif, kognitif dan psikomotorik. Oleh sebab itu guru bidang studi bahasa Indonesia agar dapat mempelajari secara lebih mendalam terkait konsep mind map dan memilki kemampuan pedagogik agar tercipta suasana kelas yang menyenangkan tidak membosankan. Hasil penelitian ini hendaknya dapat menjadi masukan bagi guru mata pelajaran bahasa Indonesia dan guru bidang studi lainnya yang pada umumnya dalam upaya peningkatan mutu pendidikan dimasa akan datang.

\section{DAFTAR PUSTAKA}

Agustina, S. 2017. Pembelajaran Bahasa Indonesia Berbasis Teks(Jurnal Bahasa dan Sastra). Aksara: Unila FKIP Jurusan Bahasa dan Seni.

Arikunto, Suharsimi. 2014. Prosedur Penelitian Suatu Pendekatan Praktik. Jakarta: Rineka Cipta.

Ariesta, F.W. 2019. Nilai Moral dalam Lirik Dolanan Cublak-Cublak Suweng. Jurnal Ilmu Budaya. Vol. 7, No. 2, 188192

Baryadi. 2016. Pembelajaran Bahasa Indonesia Berbasis Teks dalam: Artikel pada Seminar Nasional STKIP Santu Paulus Ruteng, Manggarai, Flores, NTT.

Buzan, Tony. 2010. Buku Pintar Mind Map. Jakarta: PT Gramedia Pustaka Utama.

Buzan, Tony. 2012. Buku Pintar Mind Map. Jakarta: PT Gramedia Pustaka Utama

Cahya, 2017. Kontribusi Psikologi Pendidikan (on line) aldinurcahya23- wordpress-com. diakses 19 Juni $2 \mathrm{O} 2 \mathrm{O}$.

Edwards, S dan Cooper, N. 2010. Makalah Mind Mapping as a Teaching Resource dalam : The clinical Teacher, 7: 236239.

Junaidi, J., Hamuddin, B., Simangunsong, W., Rahman, F., Derin, T. ICT Usage in Teaching English in Pekanbaru: Exploring Junior High School Teachers' Problems. International Journal of Advanced Society and Technology, 29 (3), 5052-5063

Kosasih, E. 2014. Jenis-Jenis Teks dalam Mata Pelajaran Bahasa Indonesia SMA/MA/SMK. Bandung: Yrama Widya.

Mulyana. 2017. Pembelajaran. Model atau Metode Pembelajaran Berbasis Teks (Text-Based Instruction/Genre-Based Instruction). Kemendikbud, Dirjen Dikdasmen Direktorat PSMP. (on line) ainamulyana.blogspot.com di akses 11 Desember 2019.

Nofitasari, D.V., Rosyadi,I., Muslimin, M., Hendrawan, R., Yudistio,K., Sa'adah, Z., Dharmawan, A.S. 2020. Harmonisasi Masyarakat Tengger dalam Upacara Yadnya Karo. Jurnal Ilmu Budaya. Vol. 8., No. 1, 140-145.

Riski, Hasria, Rahman, Fathu, Sadik, Andjarwati. 2018. Improving The Students'speaking Ability Through Silent Way Method At Smu Negeri 12 Makassar. Jurnal Ilmu Budaya, 6 (2), 303-312

Sarimanah, Eri. 2017. Desain Sintak Pembelajaran Bahasa Indonesia Berbasis Teks Melalui Implementasi Lesson Study dalam: Seminar Nasional Program Studi Pendidikan Bahasa Dan Sastra Indonesia. Pontianak: Universitas Pakuan Indonesia. 